\title{
Co-Management Approach And Its Impact On Women's Livelihood Strategies: Lawachara Protected Forest Area Perspective
}

\author{
Md. Mynul Islam \\ Department of Women and Gender Studies \\ University of Dhaka
}

\begin{abstract}
Women's position has not changed greatly in the patriarchal society of Bangladesh. The cultural interpretation of social practices creates a lot of obstacles for women to survive properly. Most of the time conventional development projects and policies prefer men's issue to ensure their rights and opportunities rather than women's as human being. Today's socio-economic political situation has also affected poor people's livelihood improvement especially for the poorest of the poor group. Among them, forest areas women are living in the most vulnerable situation to meet their livelihood. They have to face unthinkable problem to maintain their livelihood strategies as they do not have enough food, education, voice, power to exercise their capacity to bring some changes in both public and private places. To improve forest areas people's livelihood strategy USAID/Bangladesh is playing a very significant role in association with states initiatives. They identified some areas as protected areas to take innovative development projects named co-management approach to development local people's sustainable development. Lawachara is one of the oldest protected forest areas, under co-management approach in Bangladesh and USAID/Bangladesh has already launched different types of strategy to improve local people's livelihood and as well as natural resource development. Through comanagement approach women in Lawachara are now really having some positive changes regarding their livelihood improvement but still there are some problems regarding policies, implementation strategies, monitoring and evaluation strategies. Greater recognition of this problem will be helpful for women in Lawachara to improve their livelihood strategies by incorporating gender issues into different mechanisms. In this regard this study examines the co-management approach from gender perspective to analyze the improvement of women's livelihood strategy.
\end{abstract}

Keywords: livelihood, co-management, patriarchal society

$$
\begin{aligned}
& \text { تلخيص }
\end{aligned}
$$

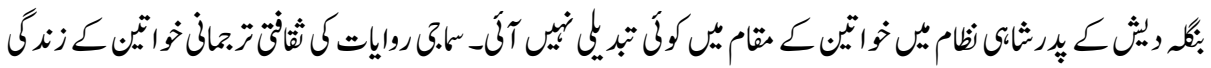

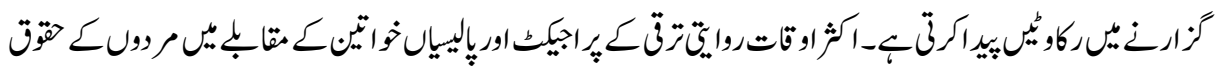

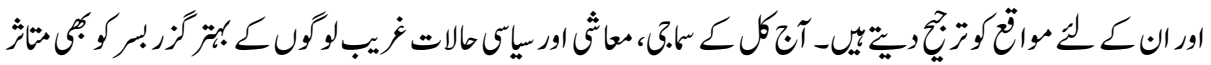

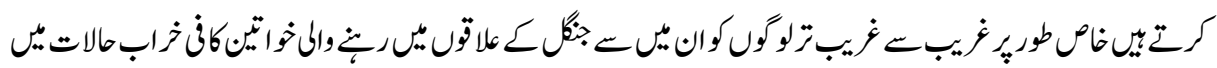




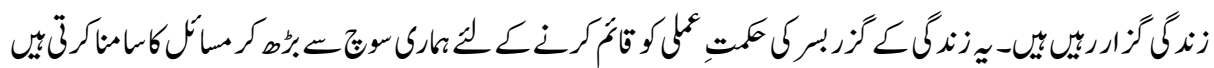

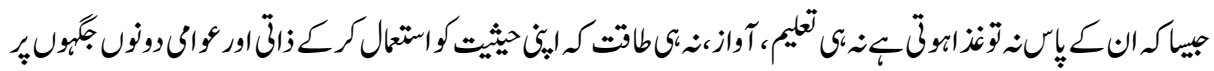

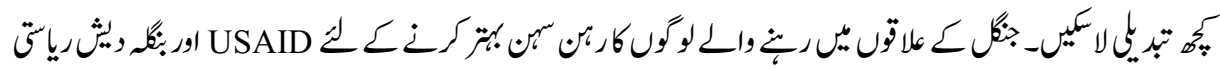

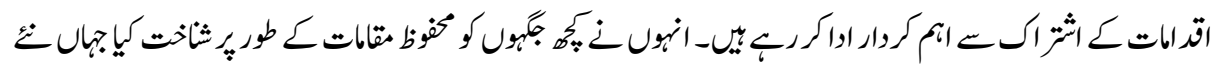

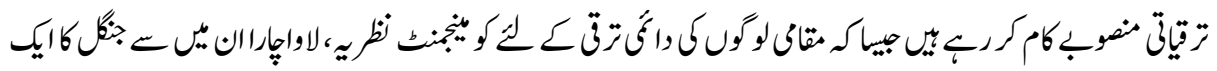

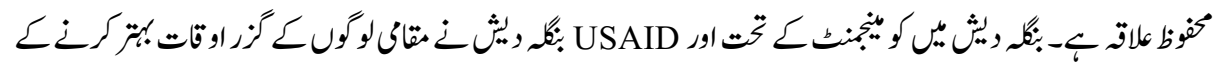

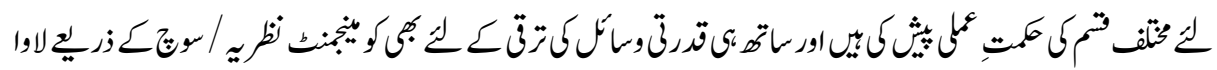

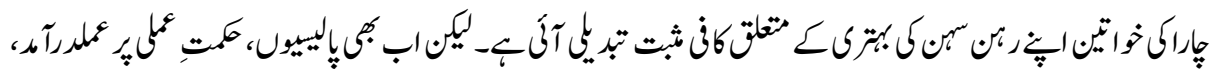

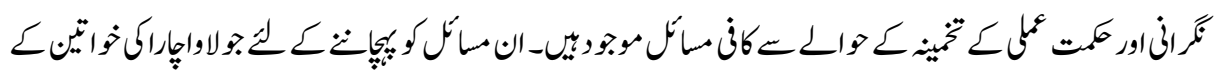

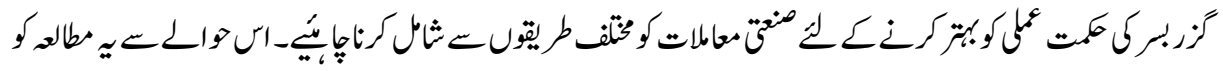

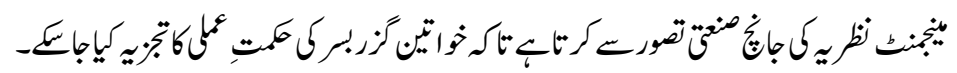

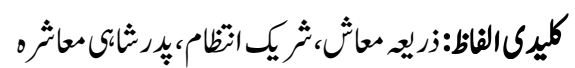

\section{Introduction}

People's livelihood strategies have been threatened by various ways in today's social, economic and political environment. Moreover, patriarchal notion of our cultural practices have always supported men's agendas to improve their livelihood strategies rather than women. Like patriarchal attitude some development projects have also resulted in mass displacements, environmental degradation and destruction of natural resources. In addition sustainable forms of agriculture are disappearing and climate changes have worsened the situation. Loss of livelihood options and traditional sociocultural structure of our country have brought different types of exploitation. In this perspective, women perennially suffer the most in terms of their livelihood management to survive. Nevertheless the global phenomena of women's work as cheap option to ensure sustainable development and targeting women through promotion of such program which makes women more dependent rather self reliant and leading to extreme poverty. In this perspective, the government organizations and non-government organizations are working together to ensure women's rights and sustainable development to make a gender sensitive equal society in Bangladesh. Besides, USAID/ Bangladesh has been introduced co-management approach to ensure people's agency and power to decide about their rights to improve their livelihood strategies in protected forest areas. Under co-management approach USAID/Bangladesh has taken a lot of different initiatives to change both men and women's situation and improve forest's condition and security in protected areas. 


\section{Statement of the Problem}

In Bangladesh, traditional patriarchal society has a very little concentration on issues of women's empowerment; even this biased situation will also be same in matriarchal tribal societies. Women have to struggle a lot to get proper access to food, education, resources and to achieve power to take active decision by their own everywhere in Bangladesh no matter it is land or forest areas. In Lawachara protected area, women still have to face a lot of problem regarding their livelihood as they do not have much formal education and access to information. Approximately $70 \%$ of Khasia, $79 \%$ of Tripura and 50\% of Manipuri people in Lawachara live in kacha house (Ahsan, 2006). Most of them are engaging in farming activities and highly dependent on nearby forest resources for fuel wood and food. Normally these people do not directly collect fuel wood from the park, but rather they have to purchase it from illicit fellers. All these communities' people are aware of tourism facilities but they are not getting the actual benefits from its different strategies. If we compare this situation between men and women then it would be clear to us that due to lack of bargaining power and social recognition women are not the actual beneficiaries like men. Another important thing is most of the women's weaving is only considered for their domestic uses instead of commercial marketing (Ahsan 2006) as they do not have access to the so called men's world. It is an emergency issue to take some necessary steps to improve women's livelihood strategies by solving the infrastructural and social problem. USAID/Bangladesh provides financial support under co-management approach to improve local people's livelihood strategies in this regard.

The government of Bangladesh is greatly committed to integrate gender issues in all policy and management levels to ensure gender balanced society. USAID has also been incorporated gender issues in co-management approach to ensure women's rights to support national initiatives. In this regard, the aim of this research is to examine comanagement approach from gender perspective to analyze the real changing perspective between men and women in Lawachara protected area. Gender analysis can help us to find out gap in existing management approaches to improve women's livelihood and to take necessary strategies to reduce the existing obstacles.

\section{Background Information of the Study}

In Bangladesh women bear many of the marks of a 'disadvantaged minority' in the social, political and economic realms (Mahtab, 2007). There is a common perception and expectation about women staying at home, to do particularly home based work and care for the children. Traditional, cultural, social and religious values and practices have reinforced the lower status of women accorded to them in society and have limited their opportunities to employment and participation in overall development process (MOWCA, 1997). As 
regards development of women in Bangladesh are far behind than men. About $46 \%$ of the population lives below the poverty line of which two-thirds are female. Most of the women belong to poorest group and around 70\% women and children in Bangladesh suffer from nutritional deficiency anemia. The male nutrient intake is higher than females at all ages (Mahtab, 2007). Over 90\% female headed households in Bangladesh are considered to fall below the poverty line (UNDP, 1996). The income of female headed households is $40 \%$ lower than male headed household (Mahtab, 2007). In forest areas women are suffering more than land areas, because they are totally depended on forest and natural resources. They have to collect food, fuel, and fodder from the forest for their livelihood. Only declaring co-management approach for protected area would not be benefited for the local people's livelihood development. We have to stop steady loss of biodiversity. We have only $6.7 \%$ forest from $10 \%$ in $1990 .{ }^{1}$ Low income household perceive threat to their livelihood from reduced access to forest biomass in different ways. Not only has that local poor people developed the forest resource but they no control of it because of lack of political power. Among them mostly women are facing problem a lot, because they have very limited access to education, land, assets, income, agricultural services and decision making process. Religious misinterpretation (by addressing misconception of purdah) makes another obstacle to support women themselves.

The government of Bangladesh ratified Convention on the elimination of all forms of discrimination against women with reservation on article 2 and 16 (1c) to eliminate gender discrimination and ensure gender equality in 1984 and participated in Rio conference in 1992 and adopted agenda 21 (Chowdhury 1995 in Dhali 2012) to ensure sustainable forestry. It is also committed to achieve Millennium Development Goals (MDG) to ensure gender equality and environmental sustainability. Therefore the government of Bangladesh is sincere to converse forest in addition to include gender sensitivity in all aspects of policies, programs and management. Since $19^{\text {th }}$ century Bangladesh has been applying a lot of policies and management systems for sustainable development. Sustainable development in relation to environment is essential for reducing poverty (Bass, Reid, Satterth waite and Steele (ed.) 2005). As per previous initiatives three types of protected areas were defined under the Bangladesh Wildlife Preservation Act, 1974, with the objective of conserving biodiversity and the natural environment within various forest types. The first Protected Areas had been established in the 1960s and 1970s; a second group of protected areas were declared in between 1980 and 1986 and third group since 2000 (Mukul, et al., 2008:60-61). Presently there are eighteen notified protected areas comprising ten national parks, seven wildlife sanctuaries and one game reserve under the jurisdiction of the Forest Department (Mukul, 2007).

USAID is playing a pioneering role in protecting and restoring Bangladesh's natural resources in a manner that simultaneously promotes income and livelihood growth for the rural poor while introducing and advancing good governance practices. USAID has 
developed a "co-management" approach in protected areas which devolves management authorities to local communities, whose lives are directly or independently dependent on the natural capital. Co-management approach is particularly found suitable for Bangladesh. Co-management practices have historically been implemented in forests that were open to local communities as common pool natural resources for their livelihoods. With the financial assistance of USAID, FD launched co-management program in 2003 in its five protected areas are two national parks; two wild life sanctuaries and one game reserve (Mukul, Uddin, Uddin, Khan, and Marzan 2008:65). Through this model the sustainable management of the nation's natural resource base is becoming the joint responsibility of both local communities and the central government. Bangladesh's current Poverty Reduction Strategy has embraced co-management for sustainable management of the environment. This phenomenon of diversion of forest lands for cultivation and industrialization is still continuing in Bangladesh. The diversion of forest land for agriculture is aggravated in Bangladesh in view of suitability of forest land for cultivation and a very high population depending on agriculture for their subsistence livelihood.

Still most of the women in our country face a lot of problem in terms of their livelihood management and it is also found in protected areas. Forest communities are most marginalized and vulnerable due to climate change (Koli, 2010). To address the adaptation of the forest community, co-management needs to be an effective platform for both in securing their livelihood and decision making space. The adaptive capacity of the forest dependent communities rely not merely on the limited benefits or livelihood option rather it depends on the broader livelihood security which include access to resource, decision making and other opportunities like the intuitional and forest market access (Koli, 2010). The marginal forest communities remain marginalized even in the process of transferring the control of forest management to co-management. The agenda of sharing control of forest management with co-management has not fundamentally challenged the basic distribution of property rights and access to forest benefits established in the colonial and in the post colonial periods (Koli, 2010). If the co-management approach does not touch the political and economic settings where access and opportunities are captured by elite and if it could not create the level playing field for the marginal (women are the most) people, these co-management initiatives would remain largely as rhetoric than substantial and it could lead to further vulnerabilities to the forest communities.

\section{Justification of the Study}

Women in Lawachara are highly dependent to the forest for collecting food, fodder, firewood as only they are responsible for cooking, gathering fuel and collecting fodder for the livestock and household keeping well. Co-management approaches facilitated some social motivation for local people in protected areas (Mukul, et al., 2008), but women are not actually getting the benefits due to the conventional attitude towards women in our country and also especially in forest areas (Mahtab, 2007). 
This study analyzes the women's real position in the protected area to ensure livelihood management under co-management approach. Theoretical and policy contributions that much of the research on forest management, the relationship between indigenous people and forests 'constitute a remarkable gap towards improving our understanding of how resource can be governed better'. The global concern about the environment is not a historic accident but was minor until 1980's and after 1980's onwards global politics are focused to environment and natural resource management (Chasek et al., 2006 in Dhali, 2010). There are a number of debates regarding the effectiveness of the environment and forest management. The command and control approach was the only forest management tool in the past, a number of forest management approaches are seen after 1980's onwards, among which community based management approach is influential (Nabanoga, 2005). Dryzek (1997) \& Perman et al. (2003) believe that market can be an effective policy instruments to ensure both ecological and social development while Barrow (2001) \& Blaikie (2006) argue for community management approaches. Community management approaches focus on the integration of indigenous people and their knowledge with the management system (Dhali, 2010). Though community management is one of the "vague and elusive' concepts in social science, Barrow \& Murphree (2000) consider it as a homogenous category, this attracts widespread international and Bangladesh attention.

There are number of literature which shows limitations of these approaches. For example some scholar Locke (1999) illustrate the Indian Joint Forest Management Program, argues that there is not currently an adequate conceptual or operational basis for gender planning. Locke (1999:276) also argues that 'Commonly, women are excluded or unable to participate in community institutions in Joint Forest Management Program'. Most of the study regarding these issues highly discussed on more forest areas should be brought under protected areas and co-management practices for in-situ biodiversity conservation in an agrarian economy of Bangladesh that is characterized by food deficit (revealed by Sharma, DeCose, Roy, Khan and Mazumder under a study of Nishorgo Support Project). Most of the efforts of co-management approach have demonstrated encouraging preliminary outcomes but they are still confined to a small number of PAs and need to extent to other protected areas across the country (Mukul, Uddin, Uddin, Khan, \& Marzan, 2008:65). The different literature review shows that most of the study focused on only different approaches under co-management model and but not directly from gender perspective. Koli (2010) argues that co-management initiatives are potential to enhance the adaptive capacity of the forest communities through enhancing livelihood security. It triggers me to think to examine existing co-management model from gender perspective with referencing women's issues, because social and gender analysis in natural resource management is essential not optional (Vernooy \& Zhang, 2006) and women are deprived of authority by new practices and men dealt with major economic decisions (Porodong, 2003). I think it will be helpful for USAID/Bangladesh to find out 
gaps and take gender sensitive projects, policies for women in the protected areas by establishing effective gender sensitive co-management approach.

\section{Objectives of the Study}

Major objective of my research is to analyze livelihood strategies under co-management approach from gender perspective to explore women's changing perspective regarding their livelihood strategies. Specific objectives are:

1. To examine the present livelihood program of co-management approach for women.

2. To analyze the benefits of the livelihood program

3. To explore positive changes for women under existing co-management approach.

4. To identify the constraints they face in the undertaking of livelihood program.

\section{Research Methodology and Data Collection}

This research has a broad focus on feminist research methodology. Feminists argue that traditional theories have been applied in ways that makes it difficult to understand women's participation in social life. Traditional social science has begun its analysis only in men's experiences. It has asked only the question about social life that appears problematic from within the social experiences that are characteristics for men. On the contrary, feminist methodology reveals the questions that are asked and even more significantly those that are not asked and generates its problematic from the perspective of women's experiences. It also uses these experiences as a significant indicator of the reality against which hypothesis are tested (Harding, 1987). Feminist methodology demands that we believe women's account of our lives, our lived experiences. Once women knew that they would be believed; they started disclosing rape, battering and incest (Bart and Moran, 1993). To conduct this research qualitative research method is followed. Secondary sources of data included relevant books, articles, reports of international and national bodies and other similar sources. Through in-depth interview, I have collected information. Case study has also been a method that will be used through the in depth interview. Using random sampling techniques a total of 15 women selected from research area. The age of the women's range between 20-45. They were from equal socio-economic status.

\section{Study Area}

Researcher has collected data from Lawachara protected area (1250 ha), Maulvibazar, which is a Hill forest. It was established in 1996. The main reason to choose Lawachara, because it is the oldest one among protected areas. It will be helpful for me to analyze and examine the co-management approach appropriately in Lawachara.

\section{Lawachara National Park: At a Glance}

Forest type: Tropical evergreen and semi-evergreen forest. 
Area: Approximately 1250 acres.

Flagship Species: Hoolock gibbon, capped langur, slow loris and many birds.

Settlement: 14 villages number of total villages are approximately 4500 .

Settlement: Khasia, Tripura and Monipuri live around here.

Theoretical Framework and Conceptual Tools: Gender Lens

\section{Sustainable Livelihoods Framework}

Sustainable livelihoods Framework is formalized by Carney for the DFID Livelihood Advisors Retreat in July 1998 (Carney, 1998). Although presented as rural and originating strongly within natural resource management focus (Ferrington, 1999). This framework became a generic model for DFID across a broader range of livelihoods, social development and vulnerability. Different types of trends and external factors impinge negatively on the livelihood of the poor (Hossain \& Bayes 2009). In this framework natural capital refers to natural resource stocks from which products and services are derived for livelihood. Human capital refers to the knowledge, skills etc. social capital refers to the network and connectedness. Physical capital refers to the infrastructure including roads etc. Finally financial capital entails saving, access to credit and control over resources. This framework also calls for the livelihood outcomes.

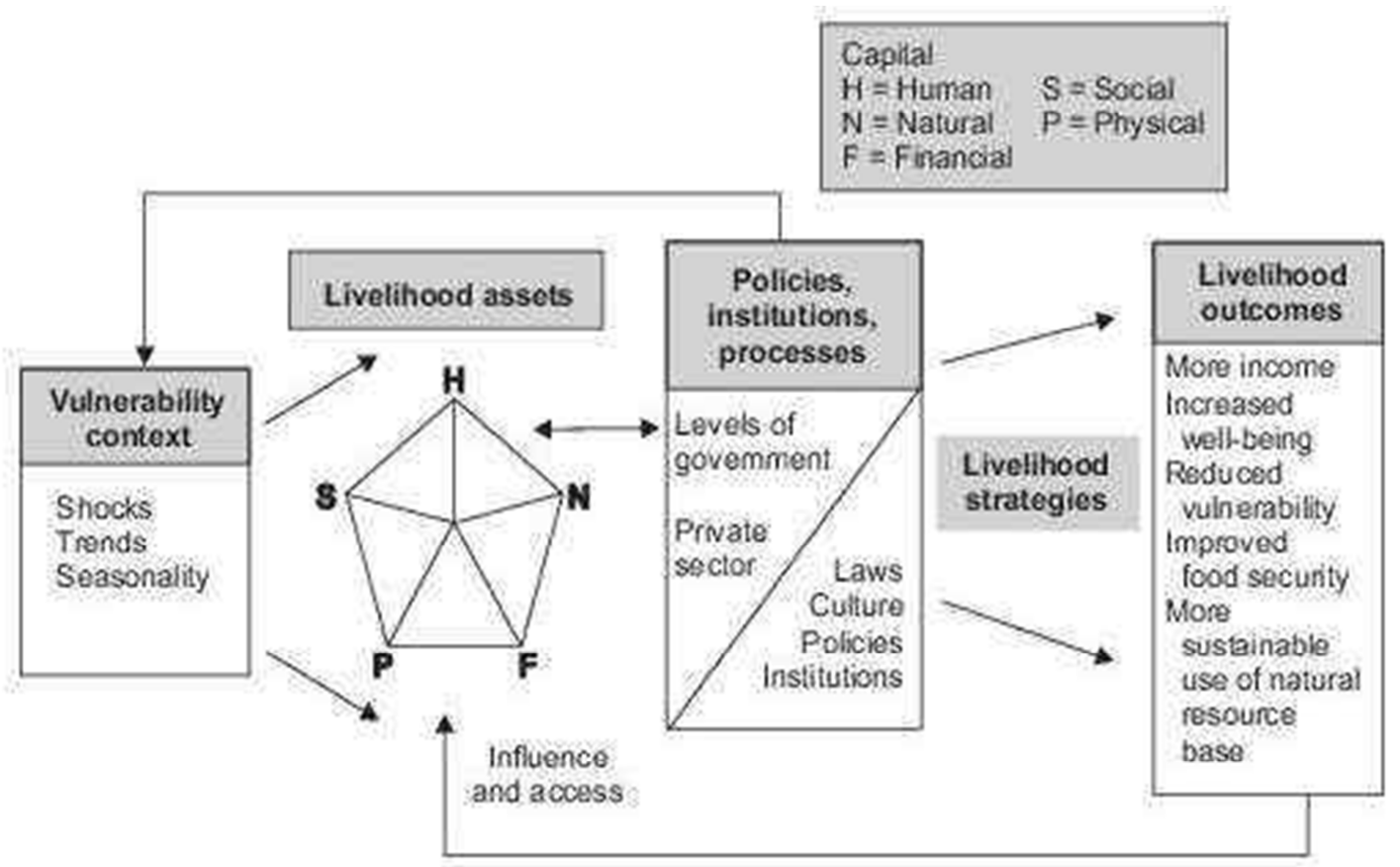

Figure: Sustainable Livelihoods Strategy. ${ }^{1}$ 


\section{Gender Relations}

Gender is a social construction indicating the differences in roles and relations between men and women given by society and it is changeable. Scott's (1896) definition of gender rests as 'an integral connection between two propositions: gender is a constitutive element of social relationships based on perceived relationships between the sexes and gender is primary way of signifying relationships of power' (1986:1067).

Gender relation is the hierarchical relation of power between men and women that tend to disadvantage women. Agarwal (1977) also sees gender relations as the power relation between men and women. To analyze gender relation Agarwal (1997) draw attention to bargaining theory and argues this model is a useful framework for analyzing gender relations. Agarwal (2001 in Dhali 2010) has set some determinants of bargaining power which are given below:

A. Determinants of intra-household Bargaining Power: 1. Personal Endowments and attributes (ownership of property, income level, educational level etc). 2. Ability to draw upon extra household support from state, relatives etc. 3. Social norms (who gets what and who does what within the household) 4. Social Perceptions (deservedness).

B. Determinants of extra-household (Community, Market, and the State) Bargaining Power: 1. Function as group or as individual, 2. Socio-economic Status and command over economic resources, 3. Support mustered from NGOs, Media, Academics, International Donors and Governmental officials.

Agarwal $(2001,1997)$ argues these two determinants can affect each other. Furthermore both men and women's capacity to bargain depends on decision making capacity in the family and outside the family, access to land, education, health, information, participation in community activities etc. In this regard, gender relation is very much related with implication of any policy or approach.

\section{Intersectionality, Patriarchy, Empowerment and Women's Agency}

The concept of Intersectionality is the infraction of multiple identities and experiences of exclusion and subordination has been heralded as one of the most important contributions of feminist scholarship (Davis, forthcoming). Intersectionality asks to reveal more disaggregated data by multiple factors such as age, status, ethnicity, religion etc. According to Cathy Davis Intersectionality refers to the interaction between gender, race and other categories of difference in individual lives, social practices, institutional arrangements and cultural ideologies of and the outcomes of these interactions in terms of power (2008). In short intersectionality means intersection of multiple identities and experiences of those people who are subordinated, oppressed and even marginalized. 
The word patriarchy literally means the rule of the father or the 'patriarch', and originally it was used to describe a specific type of 'male dominated family'- the large household of the patriarch, which included women, junior men, children, slaves and domestic servants all under the rule of this dominant male. Now it is used more generally to refer to male domination, to the power relationships by which men dominate women and to characterize a system where by women are kept subordinate in a number of ways (Bhasin, 2001). At a less abstract level, patriarchy is composed of sex structures: the patriarchal mode of production, patriarchal relations in paid work, patriarchal relation in the state, male violence, patriarchal relation in sexuality and patriarchal relations in cultural institutions (Walby, 1997). To conduct this research patriarchy concept helps to understand the patriarchal relation in the protected area and its different strategies.

Kabeer's (2001) definition of empowerment is more useful and can be applied in Bangladesh: 'The expansion in people's ability to make strategic life choices in a context where this ability was previously denied to them.' I think that this notion of 'women's empowerment' is a more political and transformatory idea for struggles that can challenge not only hegemony of patriarchy, but the mediating structures of class, religion in Bangladesh which determined the nature of women's position and condition in our society in a realistic way.

The issue of women's agency defined as the capacity of a female economic agent for rational decision-making and women's independent judgment and hence in their capacity for reasoned decisions on economic matters and women to make decisions in their long-run interest. Class, race, gender and cultural intersects are shaping women's agency in many ways. Social practices embodied in the intersection of gender, class and religion calls into question that patriarchy as the regular dominant form of social ordering. The main purpose here is to highlight how these differences combine to create women as what Makkonen defined as 'a minority within minority' (2002:19). So, women faces a lot of obstacles to ensure their agency as empowered themselves to improve their livelihood strategies.

\section{Livelihood Strategies and Changing Perspective}

\section{Livelihood Strategies under Co-management Approach}

Co-management is an approach used by government technical agencies to collaborate with local communities and other stakeholders in the conservation of forest lands, wetlands and other natural resources. To implement this approach, co-managers engage local stakeholders through a participatory process that empowers them with a voice and well defined role in decision making and provides economic incentives to engage their interest in the successful achievement of agreed upon natural resource management. Integrated Protected Area Co-management project started working in 2008 in Bangladesh to support community led co-management of natural resources which will achieve 
conservation of protected areas and alleviate poverty through income generating activities and conservation linked micro enterprises. IPAC is being implemented by the Ministry of Environment and Ministry of fisheries and livestock with technical support from a consortium of partners led by International Resources Group (IRG) and funded by United States Agency for International Development.

Communities are now receiving revenues from local eco guides, eco-rickshaw guides, elephant forest rides and sales of tourist items. Women are benefiting from technologies such as improved stoves that eliminate harmful kitchen smoke while reducing fuel wood cost. Some women have their tea stall funded by co-management project for improving earning capacities. Ethnic communities play an important role in the conservation through council. The Tripura community is now selling high quality hand-loomed products for a sustainable income.

The co-management project implement outcome activities through matching kind support to poor communities in and around the protected areas. They identify basic need through discussion with CPGs and VCF members on fish culture, nursery (plant), weaving, agriculture, homestead gardening, bamboo clump. They prepared list and data base of fish culture, agriculture, bamboo product development, homestead garden, weaving group, nursery operators, bamboo cultivation and provided grant support (in kind) and support to marketing linkage, RMOs, VCC, VCG, VCF, PF \& CMOs for ICS installation plan.

\section{Women's Perception about Livelihood Strategies under Co-management Approach}

Most of the participants argued, co-management approach is really helpful to improve their living condition. Before getting benefits from co-management approach, they had to face a lot of problem to ensure their livelihood strategies. After implementing comanagement approach (Nishorgo project and now IPAC) women are now able to change their situation with comparing past. Under this model, it has initiated different types of mechanism to change protected areas people's status and protect forests, like they provide financial support, goat, training, information and so many other related benefits. Piyaru Begum, aged 39 stated her opinion in the following way:

I think saha baosthapona songghathon (co-management approach) is very helpful for us. They have taken some important strategies to improve natural resource management and local community people's livelihood development. They gave us seeds and fishes to cultivate and improve our poor condition. Some of we are also working in buffer garden.

Besides giving material support, it also helps people to aware and practice about their rights and socio-economic benefits. Women in Lawachara are now able to compare between IPAC and other running non-governmental organizations activities in terms of 
providing loans. Like IPAC, other NGOs are not financing to the local people, which makes IPAC different and friendly rather than other NGOs credit policy. This can be identified as another success for IPAC by providing some innovative and people oriented facilities tremendously. In this perspective, Sumita Dev Barma, aged 26, and stated her opinion about co-management approach like following way:

I think this project is very good than other project (here she mentioned some running other NGO's initiative) because we do not have to pay any loan. It's totally grant.

Under the co-management approach, women are now also able to take their decision, which was completely impossible in their previous days. Women can engage themselves into different income generating activities and can contribute to their families like they can intake food at least two times and also send their daughter to the school. Besides these positive insights, there are also some gaps needed to fulfill. In this regard, IPAC needs to take some gender sensitive policies and programs from women's point of view to challenge the patriarchal discrimination, because it neglects the contribution of women and wants to reduce their visibility from public places, which is one of the major important issues to improve livelihood strategy. Mollica from Tripura community, aged 24, completed S.S.C. stated in this regard:

Yes, they have taken a lot of initiatives for changing local community people's livelihood strategies and natural resource management, but they have very less especially women focused program to improve their massive condition.

Here it is clear, co-management approach is working greatly to enhance Lawachara people's living standard and to protect natural resources. In order to protect natural resources, they have done some excellent activities to sustain it for next generation. Regarding improvement of local people's living standard and other fundamental rights, it may have to do something more than now. In our country women are more marginalized than men, so it would be tough to provide same facilities under a common notion of development model. To reduce this discriminatory situation, they have to take some women focused programs like basic education, training, law related information, reproductive and sexual rights, health and nutrition.

\section{Benefits of this Co-management Approach}

In our rural forest areas Bangladesh, the life style between men and women are totally different, if we compare. Development programs have to set up some sort of strategies so that both men and women can be benefited equally, because the socio-economic position of women is far behind men. If they do not take some women friendly steps immediately on the basis of gender equity, then women have to struggle again to get their actual benefits. Co-management approach has some potential goals to improve Lawachara 
National Park and as well as its local people. People are now benefited from this program by getting financial support, training, goat, cow and etc. Due to these various facilities, still there is a huge problem to be beneficiary for women under this dynamic model. All strategies are taken by IPAC for both men and women similarly and it causes both men and women are not getting benefits equally. Local men have a great influence on forest benefits and they are automatically privileged by the authorities. From top to bottom managing level there are only few women and they have not enough scope to raise women's issues properly. Women are getting the benefits from tentative two possible ways like a) getting financial and other supports and b) through husbands who's are member of the local forest committee. Independently women are not allowed to exercise together power to get some benefits like men. Ayesha Siddiquea, aged 25 stated like:

Here I am a new member. Recently I have married to 'Bachchar abbu' (her son's father). So I do not know the actually improvement of women. Everything is same like our village. I mean women are still facing a vulnerable position. My husband related with project and we are happy family.

In terms of Ayesha, she is not directly benefited but benefited through her husband's work in the project. There are a very few women who's are getting benefits by their own, but they have to work double than me to get the recognition. In this regard, Nurjahan Begum, aged 38, stated her opinion like following way:

They helped me to install my tea stall. That's why it possible for me to earn money. My business is seasonal you know, but I am happy with it though. I would be better off if they could help me to build another tea stall.

Piyaru Begum, stated also:

We are benefited by many ways. They gave me seeds and other things. They also gave me 1000 taka as grant. Then I have added another 500 taka to buy goat.

Renu Begum, stated her opinion like following way:

They gave me a mobile phone. It helps me to keep contact with others and stuffs. Now I can inform other female member to join in our meetings... and in case of facing any problem, $i$ can get back to our authority seeking their advice... We (20 $C P G$ members) have got some nice dresses to wear on too.

Sofura Akhter, aged 35; have talked about an important dynamics that helped change their livelihood strategies. She said like this,

They give us buffer garden, seeds of ginger and fertilizer to cultivate land alongside many other things and then earn from that. It is really helpful for us to get something, which we knew nothing in the past. 
We see women in protected area are at primary stage of getting benefits. Another important thing is that forest area is significantly different than land area and it is not a match for it. It is usually takes longer time for forest land to bear any fruit. To maximize women's benefits by way of taking women focused initiatives will be more fruitful the way Mollika stated:

Recently I have completed sewing training. After completing my training I have opened up a clothing shop. It is one of the few things that contributed to change my life. I want to thank co-management project for helping me out in this, but I do have a request, please take more initiatives for example they can ensure my employment opportunity until our problems are solved because still we are in so problem such as most of the time we cannot eat three times properly.

To enhance women's livelihood strategies, the first and foremost work should be to ensure women as top beneficiaries, because without establishing them as benefited group, how changes could be brought about in terms of livelihood strategy. Then they will decide which one is good for them or not, but to ensure that USAID needs to ensure women's focal point and women's focused project and policies containing their public and private rights. It will be the most important indicator to establish women as a part of benefited group.

\section{Changing Perspective of Women in Lawachara in Terms of their Livelihood Improvement}

In this section, here researcher analyzed about the facilities or benefits that women in Lawachara are entitled to and the changes whether it's positive or not, that it brought. To discuss their changing perspective I have emphasized on some important issues including family and outside role and activities, decision making process within family, land property, income earning activities, health and nutrition facilities, education and information facilities and finally participation and decision making process in community activities. I think these issues are more important to examine the women's changing perspective through co-management approach. To discuss this issue here I have also emphasized on issues regarding gender relations, because without questioning about gender relation, it will be difficult to examine women's changing perspective in terms of their livelihood strategies.

\section{Role and Duties: Family and Outside}

To examine the women's changing perspective, family role and outside role is an important indicator. In Bangladesh, most of the women are responsible for household working. It's a sexual division of labour within household. Most of them are not able to exercise their agency, because of so called power relation within state, society, 
community, household and family. Whether women are working home or outside the home they have to complete their household work. It will be difficult for women in Lawachara to participate work in the outside and even in the meeting, if their husbands or other family members refuse to take up their share of responsibility. For some women who work in buffer garden or some other types of garden, at that time if her family members do not want to lessen her burden of household responsibility by sharing with her, then it will be difficult for her to continue working in forest. Renu Begum, aged 40, opined like following way:

If I do not do my households work. Then who will cook, clean for my family. It's my responsibility. I have to work both at home and outside. Sometime it puts pressure on me, but what will I do? Is there any alternative way to reduce my double work?

In this perspective Sumita Dev Barma, aged 26, studied up to class 8, stated her opinion that:

Not only household work, but also I have to do some outside work for my family purpose. Sometime it will put pressure on me to complete all the work both in home and outside, but I am so fortunate sometime my husband wants to help me. That's why I can easily complete my home and outside responsibility. When guests are at home or elsewhere like at our community related cultural or marriage program, both of us work together. I think if husband and wife work together or husband can realize his wife's extra load of work then it will be helpful for every woman to continue her outside and home activities.

Another case of Mollika, said regarding this issue:

Still women are mostly confined with household work, so it will create a discriminatory situation between men and women to participate outside work and as well as household activities.

To ensure women's livelihood strategy they have to go out to exercise their agency, but only a little number of women can work outside such as guide and other garden related work regularly. Household diplomacy ${ }^{2}$ has placed women in the position of today's slave. It creates double burden for local women to continue both home based work and outside income generating activities.

\section{Decision Making Process within the Family}

Decision making capacity is an important criterion for women to ensure their empowerment. It helps them to change their livelihood strategies, through ensuring their voice to demand about their rights and needs both in public and private sphere. In our 
patriarchal society most of the women are not enough capable to take their own decision to exercise their agency. The researcher also found the similar notion of patriarchal practices in both community and project based activities in Lawachara. Here a very a few women own the opportunities to participate in decision making process for the family. Most of the women in Lawachara think that decision making is men's responsibility as they are the main income earner. Ayesha Siddiquea stated her opinion regarding this issue like following way:

All the decision in my family takes bachchar abbu (her husband) alone. Actually society teaches us to obey our husband's decision. My husband maintains all the necessary things. If he feels any problem and he is in good mood then he asks me to what can we do to solve it? Due to some financial contribution through income generating activities for family sometime he allows me to take decision. But he accepts my opinion a very little time.

Besides, a very few women also able challenge traditional gender relations after getting the benefits from CA. Different initiatives under CA helps them to earn some money through income generating activities. When a woman becomes economically independent, then she owns some power to take decision for the sake of family and challenge patriarchal rules. In this regard Renu Begum, stated:

I take all the decision of my family after my husband's death though I have a son. I do my budget. My decision is very important for my family. The entire family member respects my decision. I think it is very important for every woman to ensure their fundamental rights.

After discussing above the cases we can say decision making capacity is now really burning issue for ensuring women's economic as well as other rights to improve their livelihood strategies. Women are now more aware about their decision making right and also know it's important to exercise their power to challenge conventional patriarchal attitude towards them. Another important thing is that women are increasingly aware about their decision making right but at the same time our patriarchal or masculine practices are not ready to accept women's decision.

\section{Issues of Inheritance and Control over Land}

The discriminatory legal system in Bangladesh deprived women to get their equal property rights from their parents as men can achieve easily. Like this situation, after marriage women also deprived by their husband to get the actual control over land. Patriarchal practices only promote men to have control over land as they are the ruler of the earth. Having control over land can lead people to maintain a good life, because it is an important element to examine people's changing perspective in terms of their livelihood strategies. 
Most of the women in Lawachara protected forest area have no right to get control over land like other parts of rural Bangladesh. Sumita Dev Barma like many other women (Pyaru, Ranu etc) stated her opinion regarding this issue like following way: We have some land but all that belongs to my husband's name. I think if I have some own land or control over land, I would have been able to exercise more power to ensure my rights.

So, we see like other places in our country, women living in protected areas are also facing problem to get ownership of land. However, under this CA, women in Lawachara are now at least able to think about their land right, which is not a very simple issue for rural women.

\section{Income Earning Activities and Earning Capacity}

Co-management approaches have taken different types of initiatives to enhance women's economic empowerment. They provide seeds, fishes, money as grant, training facilities, cows, goats, pigs and many other things to improve their income earning activities. Sumita Dev Barma stated her opinion in this perspective following way:

They provide cows, goats, and pigs to improve our family condition. Also guide us how to maintain cows, goats and pigs properly to get more benefits, like we can sell extra cows, goats, pigs and cow's milk and use cow's dung as fuel. It helps us to change local women's daily life through earning some money, which was totally impossible in the past.

In this perspective Renu Begum, member of CMC, stated her opinion like following way: I have some positive changes in terms of my family income. Now I am earning money for my family. The co-management project gave me 1000 taka to buy goat. I have added more 500 taka then I bought goat. Now I am selling my goats and earning money.

Nurjahan stated her opinion regarding this income earning capacities and capacities like following way:

I am so happy. Now I have my own tea stall. My daughter works as eco-guide. My husband works in garden. So we are a happy family. All these are blessings of Almighty Allah and this co-management project. During season I earn a lot. I mean it's quite good for my family, but during off season we have to face problem to earn money.

Though they are now able to earn some money, but the amount of money is very low to maintain a family properly. Their monthly earning range is 3000 to 5000 taka mostly, which is not sufficient for living in a forest (tourist) area. Due to their living place, they 
need some work to earn more money to maintain their family in off season. Concerning this issue, Champa, aged 26 stated her opinion following way:

After completing my sewing training, now I am able to earn a little amount of money by sewing clothes (thamiee, blouses and salower kamij etc). I have a cloth shop, but customers are very seasonal and very rare in off season. My average monthly income is 3500 to 4000 taka. This little amount is not sufficient to improve my family condition and even my life. I think CA should open a home based little factory to sell our product regularly and updates us to improve the quality of our products. Besides, training program should be organized for both ethnic and non ethnic women.

However many women are now engaging themselves with income earning activities because of co- management approach. Most of them have some positive changes (at least they started to earn some money and as well as it increases their agency to challenge patriarchal gender relations) but during off season they have to face unquestionable problem to earn. To improve forest area's peoples' livelihood strategies need to take sustainable long term project and monitor the existing activities properly.

\section{Health and Nutrition Facilities}

Health and nutrition facilities are so much important issues for rural women. In our country most of time women's diseases are not treated as diseases. Under CA's different activities women are now aware about their reproductive health and nutrition rights. Due to their living area, most of the women have to face difficulties to get proper treatment during pregnancy time. They have to walk a long distance to go medical center and even they cannot manage rickshaw due mud road in rainy season. Regarding nutritious food, they only know the importance of it, but need to know the way to take proper amount of calorie and protein. Sumita Dev Barma stated her opinion in this regard:

Now I am more concerned about my health rights and other health related issues. Nutrition is very much important for us. Otherwise we cannot work properly. But we need training about reproductive health rights and children's nutrition and pregnant women's health care.

\section{Education and Information Facilities}

Education is an important tool for every woman to ensure their empowerment and to make their voices heard in order to improve their livelihood strategies. After getting the benefits from co-management approach, most of the women in Lawachara are now aware of importance of girl's education. Besides, they started to believe that it is a blessing for them because they are now able to get some important information related to health, 
nutrition, education and others through their school going children. Sumita Dev Barma stated her opinion that:

I am not that much educated, but now I am realizing that education is very much important for every person to become as independent or be empowered. I will send my son to school for being perfect human being. They provides us several information about our different issues like health, education related information. These are really helpful for us to take further initiatives about our family and as well as for us.

Few of women started to use mobile technology, which makes their life more comfortable to communicate with others and get the information quickly. By using this mobile phone, they can also contribute to protect their natural resources. Most of the women mobile user said that it makes their communication easily by informing authority very quickly to protect their buffer garden and other resources. Renu Begum stated her opinion in this perspective like following way:

Education is very much important for every person especially for women, because they are the most vulnerable and poor group in our country. From our meeting I came to know that girl's education is very much important to exercise their rights. Education is also important for natural resource management and gardening. Without proper knowledge no one can improve their socioeconomic situation. .... I have a mobile phone, so now I can easily communicate with others and get the information quickly, which was very much impossible in past. If I see anything is going wrong in our garden or our community then I can quickly communicate with our authority to take possible best initiatives to protect our resources and also ourselves.

After discussing the above cases we can easily say that co-management is really working for local people's livelihood improvement. They achieved some potential benefits and which helps them to change their situation and know about their empowerment. People in Lawachara protected forest area are now more concern about their both boys and girls education and it is an essential part for their better future. I think it is a great contribution of co-management approach.

However there are some constraints regarding education and information facilities, because still a large number of indigenous and Bengali women in Lawachara are facing problem in terms of getting education facilities. Even most of the young people are not able to go to school. So the women in Lawachara have highly demand that education should be ensured for all people, especially for women of all age. Many poor people are living here and want to study. Naturally girl children and women consist most of them, because they are the second sex. Sumita Dev Barma, stated her opinion like following way: 
There are many young people, who are keen to study, but their families are not capable to afford them. It is extremely true for girl children and women. So I think they will have to take some initiatives immediately to ensure these poor people get educated. Education can help us to make the right choice. It will be very helpful to improve our livelihood strategies.

Sofura while taking about education facilities pointed to a fact that most of the locals find difficult to comply with, that is the distances from village to school. She stated her opinion like following way,

Distance is the major cause of dropout from school and it is especially true for girls. I am worried about the security of my girls to be honest.

Sara banu, aged 35; also expressed same feelings like Sofura and also interested to donate a land to establish a girl's school. She believes it may be helpful for parents to send their girls to the school very promptly and without any fear of sexual harassment. She said that, I have a land in my possession in front of my house... They can set up primary and high school for the local children (especially for girls) if they want to. I am willing to donate it for the cause. I think parents will be satisfied to send their daughter nearest school

It is not that easy to bring about a real change in the life of the people in the region given that it's a forest land where producing resources for locals to scrap a living is much harder comparing to plain land. Education can come of assistance in this respect as it will have some immediate impact in proving their life standards.

\section{Participation and Decision Making Approach in Community Activities}

Being a citizen, every person should participate in decision making process in both public and private sphere. Participation is one of the major characteristics for ensuring women's economic, political as well as other fundamental rights. I was very surprised to see only one female member participated in CMC meeting and remained silent. One of the male members suddenly raised his hand and started to explain his demand related work policy and his voice was bold and full of confidence. Later I came to know that there are also some another female members but they were absent due to their household activities and guests. This is a major problem which reduces women from community as well as national level participation. Renu Begum was the only female member representing the other female members stated her opinion like following way;

Our patriarchal social norms advices us women's place is at home (kitchen). Men should work outside. Women's responsibility is to take care of her family and complete household responsibility. For this reason many women are not still participating here. However the situation is changing and now more women are 
participating in community meetings, because they help us to know about importance of decision making and participation for forest management and local people's development ......I am very regular in every meeting but I feel very shy to talk. Another reason of keeping silent is that if I want to say something that will be quarrel or rubbish talk (according to other male committee members). They do not emphasized on my speech...then they said to me we will think about it. So it's really a problem to say something alone with full of male member in our community meeting.

The narrative from Renu Begum indicates the social structure of our country. From my observation, one thing was very clear that not a single male member did not pay his attention to know what Renu Begum was going through with her demand and work plan. It is very tough for a woman to express her opinion alone in male dominated community meetings in rural area of Bangladesh. To participate in meeting regularly, every woman should distribute their household activities with their male partner.

\section{Impact of Tourism to Enhance Livelihood Strategies}

Tourism is often seen by economists as route to macro economic growth, by the private sector as commercial activity and by conservationists as an element of sustainable use to create conservation incentives. If tourism facilities do not directly prioritize local people then it will be problematic to enhance their livelihood strategies. Most of the people in protected area are now aware of tourism and its different prospects. Tourism facilities also help them to increase their earning capacities. Both women from ethnic community and Bengali society have some positive changes to get the benefits. Shama, aged 32 stated her opinion regarding this issue in a following way:

Tourism facilities help us to generate income during season. On that time I have to be busy with my handloom products to sell. Then I can contribute my family to run properly as other male members of the family.

Renu Begum stated her different opinion regarding these tourism facilities. She emphasized on both positive and negative aspects of traditional tourism facilities. She stated her views like following way:

Now I can earn something more during season, because of tourism facilities. It is really helpful for my family as well as to improve my personal position. But the problem is these businesses are too seasonal. I have to face some problem during off season. We always feel the necessity of a regulation that will clearly define everything related with forest, local places, and so many other issues like they have to visit this protected area in a peaceful attitude and without any harmful activities. Day by day people are increasingly doubled to visit this place during 
season, so forest areas natural resources such as birds; monkeys etc have the possibility to face problems.

It would be better if the tourism will be eco friendly and as well as its highest priorities local people's need to change their unquestionable problematic situation. It will be helpful for local people and as well as forest area's resources rather than only partial profit $^{3}$ oriented thinking. However there are some problems regarding seasonal business, because most of the women in Lawachara have argued that, co-management has given them enough facilities and opportunities to improve their condition, but it's not a 12 month stand. Mollika stated her opinion like:

We have to wait for the season to get visitors, foreigners, travelers, tourists to sell our products. Most of the tourists have no interest in paying exact price of different products, because we have no modern cloth shop and other facilities, though we have sent some of our products to nearest resident hotel's shop.

\section{Other Constraints}

Co-management is an effective approach for developing protected areas people and as well as natural resources. It helps local people to improve their livelihoods specially it also works for women. Now every person in Lawachara protected forest area have many positive changes though they have to face various constraints. Some of the constraint that I have already discussed with changing perspective of women in terms of their livelihood through my respondents case studies. Some other major constraints include (these problems are also expressed by women from Lawachara protected forest area):

\section{All Women are not Benefited through all Projects Facilities/Outcome}

According to women in Lawachara this is major problem because project does not cover all women by their different facilities. Some women benefited by seeds, some by grants (money) or some by cows or goats or pigs, but this is not a suitable way to sustainable human development. It will be difficult to maintain all the things for all women, but it needs to identify who are the most marginalized to give one more facilities.

\section{No Monthly Payment}

Women members of CPC have no monthly payment for their work. Their paying system and week counting system is so lengthy. When every members of CPC have done their weekly lot of work by rotation then they would paid and it will take a long time. For example 700 taka is fixed for every guard at the ticket counter at Lawachara National Park despite going through major health related complexities while they are starving. In this perspective Sofura has said that, 
If I take rice from my house, I can work properly on that day, but it is impossible to take food from my house daily. If they provide us some food during our duties it will be very helpful to continue our duties.

Here I want to mention two constraints that had caught my attention while visiting the area.

\section{Challenge to Conventional Tourism Approaches}

There is an emergence to review the tourism approaches. We need to promote dynamic multifaceted women and eco friendly tourism approaches, because we have to improve our local people's income growth especially women's income. Women are the poorest of the poor group in protected area, so need to more priorities towards them to enhance their situation in true sense rather than only commercial purpose. Another important thing is to enlarge or change the tourism systems or facilities. Local people's demand and their environment will be the first priority. Without emphasizing their position, tourism facilities will not be able to serve them properly and exactly. In terms of off season of tourism, there should be alternative facilities for both men and women to support their families and survive properly along with their human rights. Project should be updated to improve employment or cash income facilities under eco friendly and local people friendly tourism approaches to challenge the existing problems of tourism on the basis of time and obviously based on local people's demand. Finally project can establish some law regarding protected areas to save and ensure their peaceful life.

\section{More Concentrate on Forest Resource Management and Male Priorities}

It will be very clear to understand their main view point, if we go through all the existing policies and its members working systems and other different committees. In every meeting they have a priority concern related to natural resource management. All the leading members (local head office to CMC committee) of different committee are male except one female leader of only female members committee. I have participated in CMC committee's one of the meetings. There I have observed the people of that committee have discussed about forest and local people's development, but they did not directly emphasize on women's issue. All the members present there were male except Renu Begum as member of that committee. She was keeping mum, because she was the only women there. Male members were so active and they have bold voice to present their problems. I was really so surprised that they have discussed about forest related problems, male members responsibilities, salary related problem of their local Moulobhi but they did not mentioned about a single matter of women's issue such as how they are managing their forest related duties and household activities? In this regard, USAID Bangladesh should prepare a gender auditing and come up with the gender disaggregated data to 
know their situation and improve their livelihood strategies. For that they would have to promote equity based program and to establish a monitoring and evaluating cell to monitor and evaluate the condition and situation.

\section{Gender Relations and Women's Livelihood Strategies: Improvement and Challenges}

Still co-management approach is very innovative idea to improve protected areas natural resource management and as well as local people's integration and their sustainable development. It works a lot to improve local people's livelihood strategies. In our patriarchal society women belongs to the secondary position and they are treated as sexual being instead of human being. No one has any interest to concern about their standpoint. It will be totally impossible to challenge traditional gender relations, if we do not allow women into mainstream decision making process in everywhere by giving their access to decision, land, information, education etc. We have to give priorities towards their experiences. We have to change our traditional attitude about their problem as 'women as a category'. If we want to improve their livelihood condition in protected areas we have to concern about their some especial point of view.

To achieve sustainable development it is an emergency to take strategies from women's point of view to challenge the orthodox of development. There is a close connection between nature and women. Women are the protector of natural resources rather than consumer. We should involve more women in forest management. If we identify forest as men's place then it will be difficult for improving forest areas women's livelihood strategies. For that we have to include women as forest policy maker, leader, and address as an equal partner of human development. Another important issue goes to gender relation, because if we do not challenge the existing male biased gender relation, we cannot go far to challenge so called 'power relation' and which is very essential to improve women's status and livelihood strategies. I think all the issues in co-management is well enough but just need to emphasize more on women issue and it should be women's focused and by their practical experiences. In this regard, it does not mean men should be excluded from the initiatives. Basically it would be an equal participation based program and policies, but to achieve equal situation we have to give some extra facilities for women (equity based program and project) to reach gender equal position. In order to implement gender sensitive program and policies co-management approach has to take some awareness and vocational training based program and policies to inform women what are their right and how will they exercise it? 


\section{Concluding Remarks Strategies to Ensure Positive Changes Regarding Women's Livelihood Strategies}

There are some ideas which can help co-management to improve women's livelihood in protected area by emphasizing their experiences and standpoint. These issues are given below:

1. Most of the women have argued that, they need to include more than one facility at a time as their equity perspective, because still they are mostly marginalized group in protected areas.

2. Education/ profession oriented skill development program and capacity development program are very important issue to ensure women's livelihood strategies, because if we want to identify the impact from its different project in forest areas, here we see it will take a long time to serve people. Most of the forest areas people are facing a lot of problem because of this reason. In this perspective, co-management should take some education/ profession oriented program instead of micro loan, because it enhances poverty cycle by taking women as inclusion, exclusion, re-inclusion and re-exclusion to improve protected areas women's sustainable development as well as their livelihood strategies such as education and technology related training and workshop, health related program, artistic program and so many other things. It will help women to get benefit for longer time.

3. By analyzing different types of tourism facilities fit or conflict with development priorities in different circumstances. Tourism's contribution to livelihoods can be enhanced by adjusting decisions on what is sustainable development and how it would be better for local people to improve their livelihood strategies, in ways that reflect local people's livelihood priorities and especially on women's issues. Co-management project have to consider the assets, activities, livelihood outcomes and local both women and men's ability to cope with or influence external influences such as institutions and policies. Coping strategies of women is not same like men and is not easy to adopt all the things like men in forest areas. To consider women's situation there is a need to take some women's friendly technology for sustainable livelihood strategy.

4. In co-management approach there is no gender specialist (directly), so it's a problem for gender relation focused research and context analysis. Every woman's problem is not same. To ensure women's livelihood development; gender auditing, gender disaggregated data and gender based relation with emphasizing on women is a burning demand. It helps co-management approach by addressing context based and gender relation based analysis, because it focuses the women's experiences perspective and their standpoint.

5. Most of the time women are facing a lot of problem to go market or town due to their household responsibilities and care work. It would be better if this approach 
can arrange some home based marketing in a large scale, provide raw materials with minimum rate, training and ensure their product's price comparing with market price. Therefore it will be helpful to enhance their home based industry and ensure control over their income.

\section{Conclusions}

In protected areas co-management has played a very helpful role to sustainable development. There are lots of positive impacts as local people are now aware about their duties in terms of forest development and management. USAID/Bangladesh really takes some friendly initiative to change the rural forest areas people's livelihood in Bangladesh. They are endlessly funding for this project to gain the ultimate success by different means. To ensure position of women in terms of sustainable economic development as well as livelihood improvement, co-management can take some initiatives with emphasizing on women's standpoint and their life experiences or their views to know what types of development they need and how they need?

In this research the researcher has tried to examine the changing perspectives of women in Lawachara protected forest area in terms of their livelihood strategies. Further research can be done on how can we ensure women' s human and legal rights to ensure their livelihood strategies in forest areas (National Park), comparative study between protected areas and non protected areas to identify the successful strategy, obstacles and future guidelines . I think it is an emergency to improve women's livelihood strategy and reduce their poverty to enhance their economic security, empowerment and development to challenge the existing power relation.

\section{End Notes}

1. For further information please see, http://www.idrc.ca/cp/ev-68326-201-1DO_TOPIC.html, accessed on $10^{\text {th }}$ March, 2011.

2. Here I have used 'Household Diplomacy' to understand about the sexual/gender division of labor within household.

3. Here I have used partial profit to understand the thought about how profit goes to such a group of particular classes instead of all other classes including local forest areas poor and poorest people to improve their situation and most of the time it happens illegally. 


\section{References}

Agrawal, A. (2007). Forest, Governance, and Sustainability: Common Property Theory and its Contributions, International Journal of the Commons, Igitur Utrecht Publishing and Arching Services for ISAC, vol.1:1, pp.111-136.

Agrawal, B. (1997). 'Bargaining' and Gender Relations: Within and Beyond the House, Feminist Economics, IAFFE, vol.3:1, pp.1-51.

Ahsan, M. (2006). Perception of Tourism by Indigenous Community Living in and Adjoining Lawachara National Park, Wildlife Management and Nature Conservation Division, Sylhet, Bangladesh.

Anderson, J., Clement, J. \& Crower, L. V. (1999). Pluralism in Sustainable Forestry and Rural Development," In Pluralism and Sustainable Forestry and Rural Development, Rome: FAO.

BBS, Compendium of Environment Statistics of Bangladesh (2004). Dhaka: Ministry of Planning, Government of the People's Republic of Bangladesh.

Blaikie, P. (2006). Is Small Really Beautiful? Community Based Natural Resource Management in Malawi and Botswana, World Development, Elsevier LTD, vol.34:11, pp.1942-1957.

DeCosse, P. J. and Jayawickrama, S. S. (1996). Co-Management of Resources in Sri Lanka: Status, Issues and Opportunities, USAID's Natural Resources and Environmental Policy Project, IRG, Sri Lanka.

Dhali, H. H. (2008). 'Deforestation and its Impacts on Indigenous Women: A Case from the Chittagong Hill Tracts in Bangladesh' in Gender, Technology, and Development, Thailand: Sage Publications, vol.12:2.

Dhali, H. H. (2010). Sustainable Development, State Policy and Gender: Examining the Effect of Forest Policy of Bangladesh on Gender Relations of Indigenous People in CHT, Germany: Lambert Academic Publishing.

FAO, (2005). State of the World's Forests, Rome: FAO.

GEF (2003). Making a Difference for the Environment and People, GEF Annual Report 2003, Global Environment Facility, Washington DC. 
Islam, Md. M. (2011). The GDP Question: Perceived Injustice in Non-Valuation of Household Work, Germany: Lambert Academic Publishing.

Koli. A. (2010). Protected Area Co-management in Bangladesh -Can enhance the adaptation of the forest communities? Proc. of International Conference on Environmental Aspects of Bangladesh (ICEAB10), Japan, p.79.

Mahtab, N. (2007). Women in Bangladesh, from Inequality to Empowerment, Dhaka: AH Developing Publishing House.

Mukul, S.A., Uddin, M.B., Uddin, M.S., Khan, M.A.S.A and Marzan, B. (2008). Protected Areas of Bangladesh: Current Status and Efficiency for Biodiversity Conservation, Proc. Pakistan Acad. Sci. vol.45:2, pp.59-68.

Sharma, R A (1993). Socioeconomic Evaluation of Social Forestry in India, Ambio, vol.XXII:4, pp.219-224.

World Bank (1996). Staff Appraisal Report: India Eco-Development Project, Agriculture and Water Division, World Bank, Washington, D C.

World Bank, World Development Report (2005). A Better Investment Climate for Everyone, Washington: The World Bank, 2004a.Ltd.

Md. Mynul Islam is Assistant Professor in the Department of Women and Gender Studies, University of Dhaka, Dhaka-1000, Bangladesh. 